\title{
Sobre uma nova especie de Crustacea Stomatopoda: Squillerichtus Aragaoi (*)
}

\author{
por \\ Lejeune P. H. de Oliveira \\ (Com 1 estampa e 7 figuras)
}

Dedicamos esta nova espécie do gênero larvário Squillerichtus ao Professor Dr. Henrique de Aragão, homenageando modestamente ao orientador dos estudo hidrobiológicos e ao esforçado pioneiro que está a instalar pela primeira vez uma Estação de Hidrobiologia no Brasil.

Diagnose - pelo caracteres do telson.

Descrição - Carapaça grande. lamelosa, de forma de tronco de cone, estreitada na parte anterior, e, se alargando para a parte posterior (fig. 2), translúcida quase transparente, lisa e sem sulcos, armada de: 1.0) um rostro espiniforme, que vem de pouco antes do somito oftálmico, reto e dirigido para a frente; $2 .^{\circ}$ ) dois prolongamentos espiniformes pequenos nascendo nos ângulos ântero-laterais direito e esquerdo; 3.") dois grandes prolongamentos espiniformes nos ângulos póstero-laterais. Pela face dorsal a carapaça recobre todo o cefalotórax e o $1 .^{\circ}$ e o $2 .^{\circ}$ somitos abdominais; pela face ventral: (fig. 1) as margens nascem pouco depois dos prolongamentos espiniformes ântero-laterais e vêm como uma linha pouco ondeada.

Antênulas (fig. 3) inseridas abaixo e atrás dos pedúnculos oculares. O pedúnculo antenular se compõe de três artículos, e leva internamente, na extremidade, um flagelo multiarticulado, e externamente: de um pedúnculo comum nasce um palpo e um flagelo multiarticulado.

As antenas (fig. 4) são inseridas a pouca distância das precedentes, tem o protopódito grosso, formado de dois artículos, sendo que o $1 .^{\circ}$ da nascimento pelo bordo anterior de sua extremidade distal a uma haste curta composta de dois artículos pedunculares e de um filete multiarticulado (endopódito) e o 2." leva na sua extremidade uma grande lamina oval (o exo-

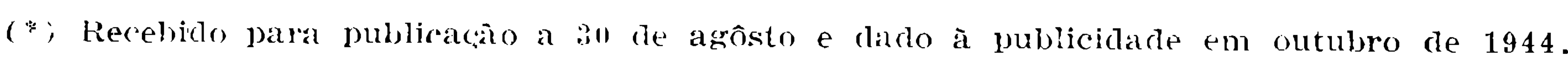


pódito antenal) com cerdas mais aproximadas na parte distal que nas margens.

Patas raptoriais (fig. 5) com os dátilos e propodos lisos. Patas torácicas dos três pares seguintes (fig. 7) escondem a bôca, cada uma delas ter mina por uma mão quelifera ovalar formada por um artículo em forma de disco no qual se insere o dátilo.

Nos três últimos somitos torácicos vê-se bem nitidamente as suturas, Em somito se insere um par de patas biramosas, delgadas, sem epipóditos, de protopódito composto de três segmentos dos quais o $2 .^{\circ}$ é o maior, o ramo anterior é biarticulado e o ramo posterior compreende um só artículo. Os três pares são todos dirigidos para trás, o $10^{\circ}$ é o menor e o $3 .^{\circ}$ é o maior.

Abdome: vista dorsal (fig. 2) os somitos que se vê (do $30^{\circ} \mathrm{em}$ diante) apresentam uma depressão mediana em baixo relêvo, e duas depressões maiores de um e de outro lado das depressões medianas. Pela face ventral (fig. 1) : 5 pleópodos, cada um com o protopódito retangular no qual se inserem o endopódito e o exopódito, lamelares e menbranosos. Exopódito dos urópodos com dois dentes na margem externa.

Telson: (fig. 6) Metade do lado direito: 3 espinulas submedianas, 1 espínula submediana, 10 espínulas intermediárias, 1 espinha intermediária, 2 espinhas laterais, 1 dente lateral, e, para fóra do dente lateral: 2 espinhas marginais. Ou, resumidamente: 2 espinhas marginais, dente lateral e 17 espinhas até ao meio.

Metade do lado esquerdo: simétrica com o lado direito.

Côr - amarelo pálido; translúcida quase transparente.

Medidas - Comprimento - $32 \mathrm{mms}$. As figuras 2, 3, 4, 5, 6 e 7 tem a indicação ao lado em milímetros.

Material - Um único exemplar, capturado por nós na enseada de Jurujuba, em 9 de Agosto de 1939, misturado com o lixo atirado pelas ondas em duas pedras situadas a $22^{\circ} 55^{\prime} 52^{\prime \prime}$ Lat. S. e $43^{\circ} 06^{\prime} 07^{\prime \prime}$ Long. W. Green'w, ao nivel do mar.

\section{EXPLICAÇAOO DA ESTAMPA}

Fig. 1 - Squillerichtus Aragaoi, vista ventral.

Fig. 2 - Squillerichtus Aragaoi, vista dorsal.

Fig. 3 - Squillerichtus Aragaoi, antênula.

Fig. 4 - Squillerichtus Aragaoi, antena.

Fig. 5 - Squillerichtus Aragaoi, pata raptorial.

Fig. 6 - Squillerichtus Aragaoi, telson.

Fig. 7 - Squillerichtus Aragaoi, 3." apêndice torácico. 

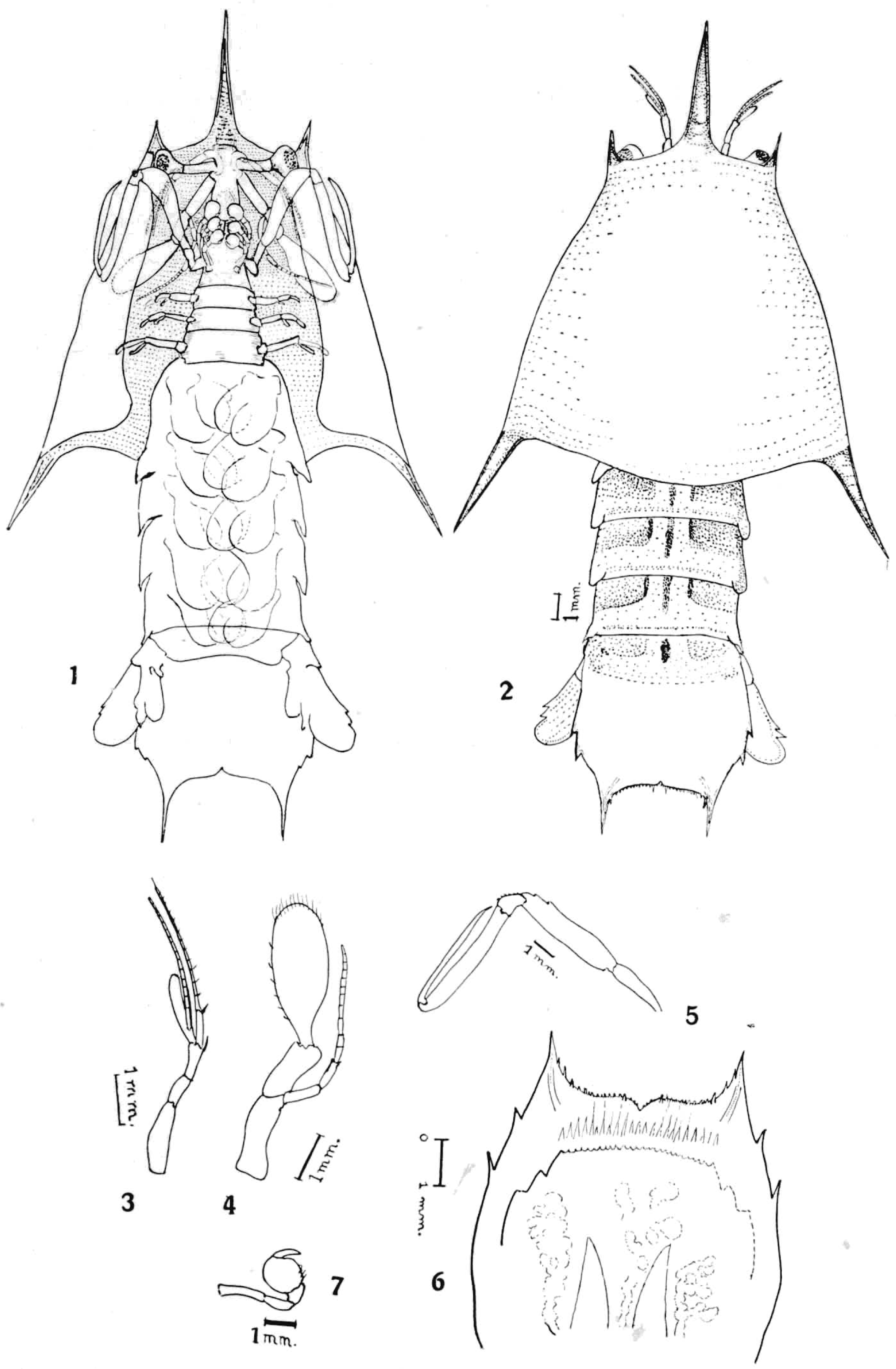

LEJEUNE P. H. DE OLIVEIRA - Sôbre uma nove espécie de Crustacea Stomatopoda: SQUILLERICHTUS ARAGAOI 